\title{
HUBUNGAN KADAR HEMOGLOBIN DENGAN JUMLAH TROMBOSIT PADA PASIEN DEMAM BERDARAH DENGUE
}

\author{
Restiayuh Patandianan \\ Max F. J Mantik \\ Firginia Manoppo \\ Arthur E Mongan
}

\author{
Bagian Patologi Klinik Fakultas Kedokteran Universitas Sam Ratulangi Manado \\ Email: restiayuh@yahoo.co.id
}

\begin{abstract}
Dengue hemorrhagic fever (DHF) is an infectious disease caused by the dengue virus and transmitted by Aedes mosquitoes. DHF affects children tend to further increase the morbidity and mortality that needed more attention, both clinical symptoms and laboratory results. In laboratory hemoglobin levels and platelet counts normal weight changes corresponding degree of illness. This research was an analytic retrospective with a crosssectional. Data sources were secondary data from medical records at BLU RSUP Prof. Dr. R. D. Kandou Manado. Samples were obtained 56 patients who met the inclusion criteria DHF of the total population sample of 137 patients. The results of the data obtained is then processed into statistical data using parametric test (Pearson test) for found the relationship between hemoglobin levels with platelet counts with $\alpha=0,05$. It was found that there was no relationship between hemoglobin levels with platelet counts $(p=0,097)$. Conclusion In this study there was no significant correlation between hemoglobin levels with platelet counts in DHF.
\end{abstract}

Keywords: dengue hemorrhagic fever, hemoglobin levels, platelet counts.

\begin{abstract}
Abstrak: Demam berdarah dengue merupakan penyakit infeksi yang disebabkan oleh virus dengue dan ditularkan oleh nyamuk Aedes. DBD yang menyerang anak-anak cenderung lebih meningkatkan morbiditas dan mortalitas sehingga diperlukan perhatian lebih, baik pada gejala klinis maupun hasil laboratorium. Pada pemeriksaan laboratorium kadar hemoglobin dan jumlah trombosit biasa mengalami perubahan. Penelitian ini bersifat analitik retrospektif dengan pendekatan cross sectional. Sumber data merupakan data sekunder dari rekam medik Depertemen Ilmu Kesehatan Anak di BLU RSUP Prof. Dr. R. D Kandou Manado. Sampel penilitian diperoleh 56 pasien DBD yang memenuhi kriteria inklusi dari total populasi sampel 137 pasien. Hasil penelitian diuji menggunakan uji parametrik (Uji Pearson), untuk mengetahui hubungan kadar hemoglobin dengan jumlah trombosit dengan $\alpha=0,05$. Uji Pearson menunjukkan tidak ada hubungan antara kadar hemoglobin dengan jumlah trombosit $(p=0,097)$. Disimpulkan bahwa tidak ada hubungan antara kadar hemoglobin dengan jumlah trombosit.
\end{abstract}

Kata Kunci: demam berdarah dengue, hemoglobin, trombosit

Demam berdarah dengue merupakan penyakit infeksi yang disebabkan oleh virus dengue dan ditularkan oleh nyamuk Ades., 1,2,3 Demam berdarah dengue telah menginfeksi lebih dari 100 negara di dunia antara lain Amerika, Afrika, Mediterania Timur terutama di Asia Tenggara. ${ }^{4}$ Data dari
World Health Organization (WHO) tahun 2011 menyatakan 2,5 milyar penduduk (sekitar $2 / 5$ dari populasi penduduk dunia di negara tropis dan subtopis) sangat berisiko terinfeksi DBD. Diperkirakan 500.000 penduduk tiap tahunnya menjalani rawat inap dan sekitar 90\% adalah anak-anak 
kurang dari 5 tahun. Data di Sulawesi Utara, dari 15 kabupaten/kota, jumlah kabupaten/ kota yang terinfeksi DBD sebanyak 9 kabupaten/kota (60\%) pada tahun 2008, 11 kabupaten kota $(73,33 \%)$ tahun 2009, 12 kabupaten kota (80\%) tahun 2010, dan 8 kabupaten/kota (53,33\%) tahun $2011 .^{5}$

Berbagai teori untuk menjelaskan Patogenesis terjadinya DBD, hingga saat ini masih diperdebatkan. Teori yang banyak dianut adalah hipotesis infeksi sekunder (seconday heterologous infection theory) ata teori antibody dependent enhancement (ADE). Hipotesis infeksi sekunder menyatakan bahwa seseorang yang terinfeksi kedua kalinya dengan virus dengue yang berbeda, maka akan terjadi reaksi dari antibodi heterolog yang telah ada sebelumnya. Ikatan virus antibodi mengaktivasi makrofag dan akan bereplikasi di dalam makrofag. Sedangkan teori ADE menyatakan bahwa adanya antibodi yang timbul justru bersifat mempercepat replikasi virus pada monosit atau makrofag. ${ }^{1,6,7}$

Pada pemeriksaan sumsum tulang penderita DBD pada awal masa demam, terdapat hipoplasi sumsum tulang dengan hambatan dari semua sistem hemopoesis, terutama megakariosit. Setelah itu pada hari kelima sampai kedelapan perjalanan penyakit, terjadi peningkatan cepat eritropoesis dan megakariosit muda. Pada masa konvalesensi sumsum tulang menjadi hiperseluler yang terutama diisi oleh proses eritropoesis dan trombopoesis dengan pembentukan eritrosit dan trombosit yang sangat aktif. Mekanisme penekanan sumsum tulang pada infeksi virus dijelaskan sebagai akibat dari proses penekanan virus secara langsung, ataupun karena mekanisme tidak langsung melalui produksi sitokin-sitokin proinflamasi yang menekan sumsum tulang. ${ }^{7,8}$

Hingga kini diagnosis DBD masih berdasarkan patokan WHO tahun 1997 yang terdiri dari 4 kriteria klinis dan 2 kriteria laboratorik dengan syarat bila kriteria laboratorik terdapat 1 hasil yang positif ditambah minimal 2 kriteria klinis. Kriteria klinis yaitu demam tinggi mendadak berlangsung selama 2-7 hari, terdapat menifestasi perdarahan (petekie, epistaksis, hematemesis dan melena), hepatomegali dan syok. Kriteria laboratorium yaitu trombositopenia $\left(<100.000 / \mathrm{mm}^{3}\right)$ dan hemokonsentrasi (Ht meningkat $>20 \%$ ). $1,9,10$

Demam berdarah dengue yang menyerang anak-anak cenderung lebih meningkatkan morbiditas dan mortalitas sehingga diperlukan perhatian lebih, baik pada gejala klinis maupun hasil laboratorium. Sampai saat ini masih sering ditemukan pasien DBD yang pada permulaan tidak berat secara klinis dan laboratorium, tetapi dalam perjalanan penyakitnya mengalami syok dan pada kasus berakhir dengan kematian. Berbagai aspek mengenai infeksi virus dengue telah diteliti untuk mengetahui faktor-faktor yang berperan menimbulkan berat ringannya infeksi virus dengue, dari parameter sederhana (pemeriksaan klinis dan pemeriksaan laboratorium rutin) hingga pemeriksaan laboratorium yang canggih. Pada pemeriksaan laboratorium rutin, pemeriksaan yang akan diperiksa antara lain: hemoglobin, eritrosit, hematokrit, leukosit dan trombosit.

Mayetti (2010) ${ }^{6}$ melaporkan dari total 295 kasus, dengan hasil kadar hemoglobin $>14$ g/dL sebanyak 104 kasus sedangkan kadar hemoglobin $\leq 14$ g/dL sebanyak 155 kasus. Kadar hemoglobin yang menjadi parameter laboratorium dengan kejadian syok, paling banyak terjadi pada kadar hemoglobin >14 g/dL sebanyak 68 kasus sedangkan kadar hemoglobin $\leq 14 \mathrm{~g} / \mathrm{dL}$ sebanyak 51 kasus dari 119 kasus yang mengalami syok. Pada penelitian jumlah trombosit Mayetti mendapatkan dari total 295 kasus jumlah trombosit $\leq 50.000 / \mathrm{mm}^{3}$ terdapat sebanyak 91 kasus sedangkan jumlah trombosit $>50.000 / \mathrm{mm}^{3}$ sebanyak 168 kasus. Dimana kejadian syok banyak terjadi pada jumlah trombosit $>50.000 / \mathrm{mm}^{3}$ sebanyak 60 kasus sedangkan jumlah trombosit $\leq 50.000 / \mathrm{mm}^{3}$ sebanyak 59 kasus dari total sampel 259 kasus. Raihan dkk ${ }^{11}$ melaporkan kejadian syok banyak terjadi pada jumlah trombosit $>50.000 / \mathrm{mm}^{3}$ yaitu sebanyak 62 kasus sedangkan jumlah 
trombosit $\leq 50.000 / \mathrm{mm}^{3}$ terdapat 41 kasus dari 113 kasus sampel yang mengalami syok. Beberapa penelitian yang penulis peroleh hanya menghubungkan hasil laboratorium dengan derajat beratnya DBD hingga syok. Sedangkan untuk menghubungkan kadar hemoglobin dengan jumlah trombosit masih belum banyak penelitian yang tersedia.

\section{METODOLOGI PENELITIAN}

Penelitian ini merupakan penelitian analitik retrospektif dengan pendekatan cross sectional. Sumber data merupakan data sekunder dari data rekam medik Depertemen Ilmu Kesehatan Anak di BLU RSUP Prof. Dr. R. D. Kandou Manado. Sampel penilitian diperoleh 56 pasien DBD yang memenuhi kriteria inklusi dari total populasi sampel 137 pasien. Hasil penelitian diuji menggunakan uji parametrik (Uji Pearson), untuk mengetahui hubungan kadar hemoglobin dengan jumlah trombosit dengan $\alpha=0,05$. Uji Pearson menunjukkan tidak ada hubungan antara kadar hemoglobin dengan jumlah trombosit $(p=0,097)$.

\section{HASIL PENELITIAN DAN BAHASAN}

Berdasarkan data-data yang diperoleh, pasien DBD yang memiliki kadar hemoglobin $<12,0 \mathrm{~g} / \mathrm{dL}$ berjumlah 8 orang $(14,3 \%)$ termasuk kategori menurun. Pasien DBD yang memiliki kadar hemoglobin 12,0-16,0 g/dL berjumlah 46 orang (82,1\%) yang termasuk kategori normal. Pasien DBD yang memiliki kadar hemoglobin >16,0 g/dL berjumlah 2 orang (3,6\%) yang termasuk dalam kategori meningkat, jadi jumlah pasien terbanyak yaitu mereka yang memiliki kadar hemoglobin normal. Distribusi kadar hemoglobin rata-rata 13,21 g/dL.

Untuk pasien DBD yang memiliki jumlah trombosit $<150.000 / \mathrm{mm}^{3}$ berjumlah 50 orang $(89,3 \%)$ yang termasuk kategori menurun. Pasien DBD yang memiliki jumlah trombosit 150.000-450.000/. $\mathrm{mm}^{3}$ berjumlah 6 orang $(82,1 \%)$ yang termasuk kategori normal. Distribusi jumlah trombosit rata rata $81.410 \mathrm{~mm}^{3}$. Pasien DBD yang berjenis kelamin perempuan lebih banyak yaitu terdapat 31 pasien, sedangkan pasien DBD yang berjenis kelamin laki-laki terdapat 25 pasien, walaupun demikian, jenis kelamin tidak memiliki hubungan dengan derajat beratnya penyakit.

Kadar hemoglobin dilihat dari nilai rata-rata jumlahnya masih dalam batas normal yaitu 13,21 g/dL. Pasien yang termasuk dalam kategori normal (12,0-16,0 $\mathrm{g} / \mathrm{dL}$ ) terdapat 46 pasien, yang merupakan jumlah tertinggi dari 56 pasien. Penelitian oleh Mayetti (2010) ${ }^{6}$ pada fase tanpa syok, nilai hemoglobin rata-rata $\leq 14 \mathrm{~g} / \mathrm{dL}$ terdapat 104 pasien dari total sampel 259. Jika dibandingkan penelitian ini dengan penelitian yang Mayetti lakukan ada persamaan yaitu pada fase awal atau fase tanpa syok kadar hemoglobin pada hari-hari pertama biasanya normal atau sedikit menurun. Tetapi, kemudian kadarnya akan naik mengikuti peningkatan hemokonsentrasi dan merupakan kelainan hematologi paling awal yang ditemukan pada DBD. ${ }^{7}$ Walaupun demikian, pada penelitian ini terdapat 2 pasien yang memiliki kadar hemoglobin meningkat ( $>16,0 \mathrm{~g} / \mathrm{dL})$, hal tersebut bisa dijelaskan oleh teori kebocoran plasma akibat peningkatan permeabilitas vaskuler yang merupakan manifestasi klinis DBD/SSD, akan tetapi patofisiologi ini belum sepenuhnya dimengerti. Kebocoran protein dan masuknya cairan ke dalam ruangan ekstravaskuler mengakibatkan hemokonsentrasi (peningkatan hemoglobin dan peningkatan hematokrit).

Trombositopenia merupakan salah satu kriteria laboratorium yang dapat menunjang diagnosis DBD. Awal pasien masuk rumah sakit biasanya nilai jumlah trombosit normal kemudian menurun dan semakin menurun sesuai dengan berat penyakit dan terjadinya perdarahan. Dari data tabel distribusi jumlah trombosit diperoleh nilai rata-rata jumlah trombosit adalah $81.410 / \mathrm{mm}^{3}$, yang berarti jumlah trombosit sudah menurun $\left(<150,000 / \mathrm{mm}^{3}\right)$. Pasien yang termasuk dalam kategori jumlah trombosit menurun $\left(150.000-450.000 / \mathrm{mm}^{3}\right)$ terdapat 50 pasien 
dari 56 pasien. Trombositopenia sendiri dilihat dari patofisiologinya dan teori-teori yang mendukung masih sangat kontoversial. Penurunan jumlah trombosit disebutkan terjadi karena adanya depresi sumsum tulang belakang atau ditemukannya kompleks imun pada permukaan trombosit yang mengeluarkan ADP (adenosine diposphat), diduga sebagai penyebab agregasi trombosit yang kemudian akan dimusnahkan oleh system retikuloendotelial khususnya limfa dan hati. Agregasi trombosit ini akan menyebabkan pengeluaran platelet faktor III yang mengakibatkan terjadinya koagulopati konsumtif. ${ }^{7}$ Pada penelitian ini terdapat 6 pasien yang memiliki jumlah trombosit dalam batas normal. Hal tersebut bisa disebabkan karena pada hari kelima sampai kedelapan perjalanan penyakit, terdapat peningkatan megakariosit muda sehingga trombosit kembali ke batas normal jumlah trombosit. ${ }^{7}$

Dari Uji Pearson yang dilakukan pada penelitian ini, ternyata tidak ada hubungan bermakna antara kadar hemoglobin dan jumlah trombosit. Hal itu dikarenakan pada awal fase demam kadar hemoglobin biasanya normal atau sedikit menurun dan pada tahap selanjutnya kadar hemoglobin akan naik mengikuti peningkatan hemokonsentrasi. Jumlah trombosit pada awal fase demam masih dalam batas normal. Perubahan trombosit mulai tampak menurun, beberapa hari setelah panas turun (fase syok). Perbedaan mekanisme antara kadar hemoglobin dan jumlah trombosit serta belum jelasnya patomekanisme dari demam berdarah dengue itu sendiri jadi dapat disimpulkan bahwa tidak ada hubungan antara kadar hemoglobin dan jumlah trombosit.

Berikut ini hasil uji statistik hubungan kadar hemoglobin dengan jumlah trombosit pada pasien demam berdarah dengue.

Hasil uji statistik dengan menggunakan uji Pearson didapatkan nilai $\mathrm{p}=0,097$ yang berarti tidak ada hubungan antara kadar hemoglobin dengan jumlah trombosit pada pasien DBD.

\begin{tabular}{llcc}
\hline & & Hb. & Tromb. \\
\hline Hb. & Pearson & 1 & -.224 \\
& Correlation & & \\
& Sig. (2-tailed) & & .097 \\
& N & 56 & 56 \\
Tromb. & Pearson & -.224 & 1 \\
& Correlation & & \\
& Sig. (2-tailed) & .097 & \\
& N & 56 & 56 \\
\hline
\end{tabular}

\section{SIMPULAN}

Berdasarkan hasil penelitian dan pembahasan yang telah dijelaskan diatas, maka dapat disimpulkan bahwa tidak ada hubungan yang signifikan antara kadar hemoglobin dengan jumlah trombosit pada paien DBD.

\section{SARAN}

Penelitian ini dapat dikembangkan pada penelitian selanjutnya dengan mengelompokkan data pasien demam berdarah dengue berdasarkan derajat penyakit dan menggunakan jumlah sampel yang lebih banyak.

\section{UCAPAN TERIMA KASIH}

Ucapan terima kasih ditujukan kepada dr. Novie H. Rampengan, SpA, DTM\&H, MCTM (TP) selaku penguji I dan kepada Prof. Dr.dr. Max F.J. Mantik, SpA-K selaku penguji II, serta kepada semua pihak yang secara langsung maupun tidak langsung telah menimbulkan gagasan dalam penulisan artikel ini.

\section{DAFTAR PUSTAKA}

1. Rampengan TH. Penyakit Infeksi Tropik pada Anak (Edisi 2). Jakarta: EGC, 2007; p.122-3.

2. Suhendro, Nainggolan L, Chen K, Pohan HT. Demam Berdarah Dengue. In: Sudoyo AW, Setiyohadi B, Alwi I, Simadibrata MK, Setiadi S. Buku Ajar Ilmu Penyakit Dalam Jilid III (Edisi V). Jakarta: InternaPublishing, 2009;p.2773. 
872 Jurnal e-Biomedik (eBM), Volume 1, Nomor 2, Juli 2013, hlm. 868-872

3. Hartoyo E. Spektrum Klinis Demam Berdarah Dengue pada anak. Sari Pediatri. 2008;10:145-50.

4. WHO. Comprehensive guidelines for prevention and control of dengue and dengue haemorrhagic fever.Revised and expanded edition. Available from: http://www.searo.who.int/LinkFiles/Dengue _DHF_prevention\&control_guidelines_rev. pdf. Cited: $7^{\text {th }}$ November 2012.77-90.

5. Kementerian Kesehatan RI. Profil Data Kesehatan Indonesia Tahun 2011. Jakarta: Kementerian Kesehatan RI;2012.

6. Mayetti. Hubungan gambaran klinis dan laboratoriun sebagai faktor resiko syok Demam Berdarah Dengue. Sari Pediatri. 2010;11:12.

7. Rena NMRA, Utama S, Pratiwi TM. Kelainan Hematologi pada Demam
Berdarah Dengue. J Peny Dalam. 2009;10:218-19.

8. Juranah, Muhadi D, Arif M, Bahar B. Uji Hematologi Pasien Terduga Demem Berdarah Dengue Indikasi Rawat Inap. Indonesian Journal of Clinical Pathology and Medical Laboratory. 2011;17:139-140.

9. Samsi TK. Penatalaksanaan Demam Berdarah Dengue di RS Sumber Waras. Cermin Dunia Kedokteran. 2000:126.p.513.

10. Wiradham D. Diagnosis Cepat Demam Berdarah Dengue. J Kedok Trisakti. 1999; 18:77-90.

11. Raihan, Hadinegoro SR, Tumbelaka AR. Faktor prognosis terjadinya syok Demam Berdarah Dengue. Sari Pediatri. 2010; 11:1. 